\title{
Chronicity in Strongyloides stercoralis infections: dichotomy of the protective immune response to infective and autoinfective larvae in a mouse model.
}

\author{
R. A. Brigandi \\ Thomas Jefferson University \\ H. L. Rotman \\ Thomas Jefferson University \\ T. J. Nolan \\ University of Pennsylvania \\ Golitow Schis ad and additional works at: https://jdc.jefferson.edu/mifp \\ Pennsylvania \\ Part of the Medicine and Health Sciences Commons \\ P. Apraham mowhow haccess to this document benefits you
}

\section{Recommended Citation}

Brigandi, R. A.; Rotman, H. L.; Nolan, T. J.; Schad, G. A.; and Abraham, D., "Chronicity in

Strongyloides stercoralis infections: dichotomy of the protective immune response to infective and autoinfective larvae in a mouse model." (1997). Department of Microbiology and Immunology Faculty Papers. Paper 139.

https://jdc.jefferson.edu/mifp/139

This Article is brought to you for free and open access by the Jefferson Digital Commons. The Jefferson Digital Commons is a service of Thomas Jefferson University's Center for Teaching and Learning (CTL). The Commons is a showcase for Jefferson books and journals, peer-reviewed scholarly publications, unique historical collections from the University archives, and teaching tools. The Jefferson Digital Commons allows researchers and interested readers anywhere in the world to learn about and keep up to date with Jefferson scholarship. This article has been accepted for inclusion in Department of Microbiology and Immunology Faculty Papers by an authorized administrator of the Jefferson Digital Commons. For more information, please contact:

JeffersonDigitalCommons@jefferson.edu. 


\title{
CHRONICITY IN STRONGYLOIDES STERCORALIS INFECTIONS: DICHOTOMY OF THE PROTECTIVE IMMUNE RESPONSE TO INFECTIVE AND AUTOINFECTIVE LARVAE IN A MOUSE MODEL
}

\author{
RICHARD A. BRIGANDI, HARRIS L. ROTMAN, THOMAS J. NOLAN, GERHARD A. SCHAD, AND DAVID ABRAHAM \\ Department of Microbiology and Immunology, Kimmel Cancer Center, Thomas Jefferson University, Philadelphia, Pennsylvania; \\ Department of Pathobiology, University of Pennsylvania, School of Veterinary Medicine, Philadelphia, Pennsylvania
}

\begin{abstract}
Strongyloidiasis is an intestinal disease that can last for decades due to the occurrence of autoinfective larvae (L3a) in an infected person, which contribute to the maintenance of the population of adult worms in the intestine. The goal of the present study was to determine if L3a are susceptible to the protective immunity that targets the infective stage of the worm, the third-stage larvae (L3). Mice immunized and challenged with Strongyloides stercoralis L3 kill more than $90 \%$ of challenge larvae contained within diffusion chambers. The L3 do not remain antigenically static in mice, however, but undergo some degree of antigenic change before they are killed, becoming host-activated larvae $(\mathrm{L} 3+)$. The $\mathrm{L} 3 / \mathrm{L} 3+$ are killed in this model system by the combined effects of both parasitespecific IgM and eosinophils. Mice immunized with L3 were able to kill L3/L3+, but did not kill L3a, in challenge infections. Eosinophils were, however, present in diffusion chambers containing L3a, and IgM bound to the surface of L3a. We hypothesized that differential IgM recognition of soluble L3a, L3, and L3+ antigens is the reason why the immune response generated against L3 could not kill L3a. Many common antigens on L3, L3+, and L3a were recognized by serum from mice immunized with $\mathrm{L} 3$, as determined by immunoblotting. However, several unique $\mathrm{L} 3$, L3+, and L3a antigens were also recognized by immune serum, thus indicating that antigen recognition with IgM antibodies is different between the $\mathrm{L3}, \mathrm{L3}+$, and $\mathrm{L} 3 \mathrm{a}$ stages. This difference in antigen recognition could explain why $\mathrm{L} 3 \mathrm{a}$ are able to evade the immune response that targets $\mathrm{L} 3 / \mathrm{L} 3+$ in chronically infected hosts.
\end{abstract}

Strongyloides stercoralis has two morphologically distinct filariform third-stage larvae in its life cycle: the infective third-stage larvae (L3) responsible for initiating infection and autoinfective larvae (L3a), which cause chronic infection in the host by periodically developing into new adult worms. ' In immunosuppressed individuals, L3a can dramatically increase in number and sometimes disseminate throughout the host, causing fatal hyperinfection or disseminated infection. ${ }^{2}$ The L3a stage naturally occurs in humans, monkeys, ${ }^{3}$ dogs, ${ }^{1.4}$ and experimentally in jirds. ${ }^{5}$ Drug treatments of individuals with hyperinfection syndrome have been conducted with variable success; $;^{2.6}$ studies attempting to generate immunity to the L3a that cause hyperinfective disease have not been reported.

Mice infected with $S$. stercoralis have allowed a rigorous examination of the immune response to different stages of the $S$. stercoralis life cycle. ${ }^{7-11}$ Immunity to $S$. stercoralis L3 in mice has been found to be dependent on eosinophils, IgM, and complement. ${ }^{10.11}$ If any one of these immune components is absent, then protective immunity is ablated. Isolated stages of $S$. stercoralis can be studied in this system since any one stage can be placed in diffusion chambers after development in a permissive host or in vitro. Analysis of diffusion chamber contents can then determine which immune components are present in the microenvironment of the parasite.

Mice and jirds immunized and challenged with L3 mount an immune response that kills the majority of challenge larvae within $48 \mathrm{hr}^{8 .}{ }^{8}$ Studies with the related species $S$. ratti and $S$. venezuelensis in rats ${ }^{13-16}$ and in mice ${ }^{17.18}$ indicate that L3 undergo antigenic change, becoming $\mathrm{L3}+$, within hours after they have entered these hosts. Though $\mathrm{L} 3 / \mathrm{L} 3+$ are killed rapidly in immunized animal hosts, strongyloidiasis can last for decades in humans. It has been hypothesized that autoinfective larvae are sporadically produced and develop into new adults to replace worms that have presumably died off. ${ }^{19}$ In endemic areas, where people are continually infected with the parasite from environmental sources, protective immunity to the L3/L3 + will develop; L3a may be able to resist the effects of immunity directed at infective larvae and would thus be capable of continually reinfecting the host. This would benefit the host-parasite relationship, since incoming infective larvae would be killed by the immune response, thus preventing superinfection, while autoinfective larvae maintaining chronic infection would survive. This report considers whether immunity to $S$. stercoralis L3 will protect against L3a. Antibody binding to larvae and cell types present in immunized mice were analyzed to determine whether an inability to kill autoinfective larvae is associated with a diminution in one or more essential immune components. Differences found in the immune response directed against L3 and L3a could explain L3a survival in mice immunized against infective larvae.

\section{MATERIALS AND METHODS}

Experimental animals and parasites. All mice used in these experiments were male $\mathrm{BALB} / \mathrm{cByJ}$ mice obtained from Jackson Laboratories (Bar Harbor, ME), 6-9 weeks of age at the beginning of each experiment. The mice were maintained in micro-isolator boxes (Lab Products Inc., Maywood, NJ). Jirds were obtained from Tumblebrook Farms (West Brookfield, MA).

Strongyloides stercoralis L3 were obtained from the fresh stools of a laboratory dog infected with the parasite according to methods previously described. ${ }^{20}$ Larvae were collected and washed by centrifugation and resuspension in sterile 1: 1 National Cancer Institute tissue culture medium-135 and Iscove's modified Dulbecco's medium (NI medium) with $100 \mathrm{U} / \mathrm{ml}$ of penicillin, $0.1 \mathrm{mg} / \mathrm{ml}$ of streptomycin, and 0.1 $\mathrm{mg} / \mathrm{ml}$ of gentamicin (antibiotics) (Sigma Chemical Company, St. Louis, MO). 
The L3+ were generated by giving naive mice a subcutaneous dose of 5,000 L3 prepared as above. After $24 \mathrm{hr}$, the mice were anesthetized with methoxyflurane (PitmanMoore, Inc., Mundelein, IL) and killed by cervical dislocation. The skin and muscle tissue were minced, placed in phosphate-buffered saline (PBS) at $37^{\circ} \mathrm{C}$, and the larvae were allowed to migrate out and then collected.

The L3a were obtained from jirds immunosuppressed with methylprednisolone acetate (MPA). ${ }^{5}$ Jirds were given MPA at a dose of $33 \mathrm{mg} / \mathrm{kg}$ of body weight followed three days later by a repeat injection in conjunction with an injection of 10,000 live L3; MPA injections were given weekly thereafter. Before the jirds succumbed to the hyperinfection, approximately 18 days postinfection, they were killed and the lungs were removed, chopped, and placed in a buffered saline solution ${ }^{21}$ at $37^{\circ} \mathrm{C}$ to allow the L3a to migrate out. The larvae were kept at $37^{\circ} \mathrm{C}$ and placed into a low gelling temperature agar mixture with a final concentration of $1 \%$ agar. After solidification and while still at $37^{\circ} \mathrm{C}$, the $\mathrm{L} 3 \mathrm{a}$ were allowed to migrate out, collected into warm NI medium with antibiotics, and cleaned by centrifugation as above.

Immunization and challenge infection protocol. Mice were immunized with live $S$. stercoralis L3 as described previously. ${ }^{8}$ Mice were given two doses of 5,000 live L3 two weeks apart followed by a challenge of either 50 live L3 or jird-derived L3a in diffusion chambers one week after the booster immunization. Diffusion chamber construction and mouse challenge infections followed previously published methods. ${ }^{8}$ Briefly, 14-mm Lucite (Millipore, Bedford, MA) rings were covered with $2.0-\mu \mathrm{m}$ pore-sized Isopore membranes (Millipore). The rings were held together with a 1:1 mix of 1,2-dichloroethane (Sigma Chemical Company) and acryloid resin (Rohm and Haas Co., Philadelphia, PA). The 2.0- $\mu \mathrm{m}$ membranes were attached to the ring with cyanoacrylate adhesive (Super Glue Corporation, Hollis, NY). The completed diffusion chambers were sterilized in $100 \%$ ethylene oxide.

Immunized and naive mice were anesthetized with doses of $0.1 \mathrm{ml} / 10 \mathrm{~g}$ of body weight of a $10 \%$ solution of a ketamine hydrochloride (Park-Advise, Morris Plains, NJ)/acepromazine maleate (Aveco, Fort Dodge, IA) mixture. Chambers were implanted in a subcutaneous pocket created on the lower back/fiank of these mice. After $24 \mathrm{hr}$, the mice were anesthetized with methoxyflurane, killed by cervical dislocation, and exsanguinated. Chambers were removed from the mice and the contents were assessed for larval viability and cellular infiltration. Cells from the chambers were centrifuged onto slides using a Cytospin 3 (Shandon Inc., Pittsburgh, PA), and then stained with Diff-Quik ${ }^{\circledR}$ (Baxter Healthcare Corp., Miami, FL) for differential cell analyses. Cell analyses were also made on blood smears obtained from the blood of the exsanguinated mice.

Surface staining. Fifty microliters of undiluted pooled mouse serum was placed with 100-400 live $S$. stercoralis L3 or L3a at $37^{\circ} \mathrm{C}$ for $2 \mathrm{hr}$. Pooled mouse serum was obtained from 5-7 individual mice. One aliquot of worms was placed in serum from mice that had been immunized, and the other was placed in serum from control mice. Serum from naive mice challenged for $24 \mathrm{hr}$ with $50 \mathrm{~L} 3$ in diffusion chambers was defined as control serum. The worms were then washed five times in PBS, and were placed in individual wells in a 96-well, round-bottomed ELISA plate. Rat antimouse IgM antibodies (Sigma Chemical Company) were diluted 1:20 in PBS, and $50 \mu \mathrm{l} /$ well of these solutions were allowed to stand with the worms for $1 \mathrm{hr}$ at $37^{\circ} \mathrm{C}$. The worms were washed four times in PBS to remove excess antibody, and once in a $1 \%$ formalin-PBS solution. Worms were placed on slides, and fluorescence was analyzed using fluorescent microscopy.

Western blots. Antibodies for Western blotting were obtained from the following sources: goat anti-mouse IgG1, goat anti-mouse IgG2a, goat anti-mouse IgG2b, goat antimouse IgG3, goat anti-mouse IgA alkaline phosphatase conjugate, goat anti-mouse IgM, and rabbit anti-goat IgG (heavy plus light chain) biotin conjugate (Sigma Chemical Company); goat anti-mouse IgE (ICN Biomedicals, Costa Mesa, CA). All were used at a concentration of $10 \mu \mathrm{g} / \mathrm{ml}$ except for anti-IgG3 and anti-IgM, which were used at 5 and 2.5 $\mu \mathrm{g} / \mathrm{ml}$, respectively. ExtrAvidin ${ }^{\star}$ alkaline phosphatase (Sigma Chemical Company) was used at a dilution of 1:400.

Serum used in the Western blots were of three types: normal, control, or immune. Normal serum was obtained from mice that had no contact with the parasite, and control serum came from mice challenged for $24 \mathrm{hr}$ with $50 \mathrm{~L} 3$ in diffusion chambers. No differences were seen in the results obtained with these two serum sources in the Western blots; they were therefore used interchangeably. Serum from immunized mice that successfully eliminated challenge infections was defined as immune serum. Sera were pooled according to group, sterilized through a $0.2-\mu \mathrm{m}$ filter, and stored frozen at $-80^{\circ} \mathrm{C}$ until used.

Aliquots of approximately $10,000 \mathrm{~L} 3$ or $\mathrm{L} 3+$ in $10 \mu \mathrm{l}$ of double-distilled water were brought to a volume of $500 \mu \mathrm{l}$ using sodium dodecyl sulfate (SDS) sample buffer (2\% $[w / v]$ SDS, 4\% [v/v] $\beta$-mercaptoethanol [Sigma Chemical Company]), $50 \mathrm{mM}$ Tris-Cl, pH 8.0, (Bio-Rad Corporation, Hercules, CA), and 5\% (v/v) glycerol (Sigma Chemical Company). Aliquots of 300-800 L3a in $5 \mu$ l of double-distilled water were brought to a concentration of $100 \mathrm{~L} 3 \mathrm{a} / 5 \mu \mathrm{l}$ of SDS sample buffer. The samples were boiled for $10 \mathrm{~min}$ before use for SDS-polyacrylamide gel electrophoresis (SDS-PAGE).

The protein samples and protein standards (Bio-Rad Corporation) were separated in one dimension by SDS-PAGE using $12 \%$ polyacrylamide $0.75-\mathrm{mm}$ slab gels with a $4 \%$ polyacrylamide stacking gel in a Mini-Protean II apparatus (Bio-Rad Corporation). ${ }^{22}$ Samples were prepared as described above and loaded on the gel with standards in separate wells. All electrophoresis was done at $25 \mathrm{~mA}$ constant current and was stopped when the dye front reached the end of the gel (approximately $1 \mathrm{hr}$ ). Relative molecular weights $\left(M_{r}\right)$ were determined for the protein sample as described by Shapiro and others. ${ }^{23}$

Proteins from SDS-polyacrylamide gels were transferred to nitrocellulose $(0.45 \mu$; Bio-Rad Corporation) by the method of Towbin and others. ${ }^{24}$ Gels were equilibrated $25 \mathrm{~min}$ in transfer buffer ( $25 \mathrm{mM}$ Tris, $200 \mathrm{mM}$ glycine [Bio-Rad Corporation], 20\% [v/v] methanol [Fisher Scientific, Pittsburgh, PA]) and transferred at $100 \mathrm{~V}$ constant voltage in a Trans blot apparatus (Bio-Rad Corporation) for $1 \mathrm{hr}$ and $20 \mathrm{~min}$. After transfer, the membranes were washed in PBS. Coomassie staining was done by placing the membranes in stain 
TABLE 1

Effect of infective third stage larvae (L3) immunization on the survival of an in vivo derived autoinfective third stage larvae (L3a) challenge infection contained within diffusion chambers

\begin{tabular}{llcc}
\hline $\begin{array}{c}\text { Mouse } \\
\text { treatment }\end{array}$ & $\begin{array}{c}\text { Type of } \\
\text { challenge } \\
\text { larvae }\end{array}$ & $\begin{array}{c}\text { Percent larval } \\
\text { survival } \\
\text { (mean } \pm \text { SD) }\end{array}$ & $\begin{array}{c}\text { Eosinophil } \\
\text { count* } \\
\text { (mean } \pm \text { SD) }\end{array}$ \\
\hline None & L3 & $81 \pm 4$ & $2.0 \pm 2.2$ \\
Immunized & L3 & $4 \pm 3 \dagger$ & $32.5 \pm 22.8 \dagger$ \\
None & L3a & $34 \pm 11$ & $3.0 \pm 2.8$ \\
Immunized & L3a & $32 \pm 10$ & $21.8 \pm 16.3 \dagger$ \\
\hline $\begin{array}{l}* \text { Given as eosinophils } \times 10^{-5} / \mathrm{ml} . \\
+P<0.05\end{array}$ & &
\end{tabular}

$+P<0.05$.

(1\% [w/v] Coomassie Brilliant Blue R-250, 0.1\% [v/v] glacial acetic acid, 9\% [v/v] methanol [Fisher Scientific]) for 1 $\mathrm{min}$ and washing in 50\% [v/v] methanol for 5-10 min.

Western blot analysis was done using a modification of a cross-linking protocol. ${ }^{25}$ Immune detection was done using biotin-conjugated anti-mouse isotype antibodies and ExtrAvidin alkaline phosphatase. The nitrocellulose was cut into strips and unused protein binding sites were blocked with a solution of $5 \%(w / v)$ Carnation brand nonfat dry milk (Nestle Food Company, Glendale, CA), 2\% (w/v) Ficoll-400, 2\% (w/v) polyvinylpyrrolidone (Sigma Chemical Company), and $50 \mathrm{mM}$ Tris-Cl, pH 8.0 (Bio-Rad Corporation). The strips were then incubated with serum diluted in PBS for 18 hr at $4^{\circ} \mathrm{C}$; serum was diluted 1:200 for all antibody isotypes except for IgE, for which it was diluted 1:40. The blots were then washed once in cold PBS and placed in $0.25 \%(\mathrm{v} / \mathrm{v})$ glutaraldehyde (Sigma Chemical Company) to cross-link the primary antibody (from serum) with its ligand. After another PBS wash, the blots were placed in $2 \%(w / v)$ nonfat dry milk in PBS to quench any remaining active glutaraldehyde sites and prevent their reacting with the secondary and tertiary antibodies. Blots were then washed several times in PBS then in $50 \mathrm{mM}$ Tris- $\mathrm{Cl}, 150 \mathrm{mM} \mathrm{NaCl}$ (Fisher Scientific), pH 7.5 (TBS) and incubated with the secondary antibody (goat anti-mouse isotype) in $5 \%(w / v)$ nonfat dry milk in TBS at room temperature. The blots were then washed in TBS several times and incubated with a tertiary antibody (anti-goat biotin conjugate) in 5\% (w/v) nonfat dry milk in TBS at room temperature. The blots were washed in TBS, incubated with ExtrAvidin alkaline phosphatase, washed again, then developed. Immunoreactive bands were devel- oped with nitroblue tetrazolium chloride/5-bromo-4-chloro3-indolylphosphate-p-toluidine salt (Gibco-BRL, Gaithersburg, MD) in carbonate buffer (100 mM NaHCO${ }_{3}$; JT Baker, Phillipsburg, NJ), $1.0 \mathrm{mM} \mathrm{MgCl}_{2}$ (Fisher Scientific), pH 9.8, following the kit instructions.

Statistical analysis. Statistical analysis of the data was performed using multivariate general linear hypothesis multifactorial analysis of variance with Systat version 5.2 software (Systat, Inc., Evanston, IL). Probability values less than 0.05 were considered significant.

\section{RESULTS}

Naive mice or mice immunized with two doses of 5,000 live L3 were challenged with either $50 \mathrm{~L} 3$ or L3a in diffusion chambers. Table 1 shows the results from such an experiment, and is representative of four separate experiments. While L3 were killed in immunized mice, there were no differences between L3a survival in naive and immune mice, indicating that immunization with $\mathrm{L3}$ does not protect against L3a at the time points tested. Eosinophils have been shown to be the only cells that increase in number in the microenvironment of challenge larvae in mice immunized against $\mathrm{L} 3,{ }^{8}$ and are essential in killing of larvae in immunized mice. ${ }^{10}$ In this study, eosinophils increased significantly in the diffusion chambers in immune animals challenged with L3 or L3a (Table 1). Parasite-specific IgM has also been found to be essential in the immune-mediated killing of L3." The IgM from undiluted immunized mouse serum bound strongly to surface antigens of L3 and L3a, with no differences in binding seen between the two types of worms. The IgM from undiluted control serum did not bind to either worm's surface antigens.

A comparison of $\mathrm{L3}, \mathrm{L3}+$, and $\mathrm{L} 3$ a soluble antigen recognition by antibody isotypes in serum from mice immunized against L3 was performed. Antigens from L3, L3+, and L3a were separated by SDS-PAGE on $12 \%$ polyacrylamide gels and immunoblotted using isotype-specific antisera. The IgM from immune serum recognized L3 and L3+ antigens, with a band of $35 \mathrm{kD}$ seen in both preparations. Additionally, specific bands of 30-64 kD were recognized in $\mathrm{L} 3$ preparations and specific bands of $42.5-76.5 \mathrm{kD}$ were seen in $\mathrm{L3}+$ preparations (Figures 1 and 2, and Table 2). The IgG1 also recognized a range of antigens in both L3

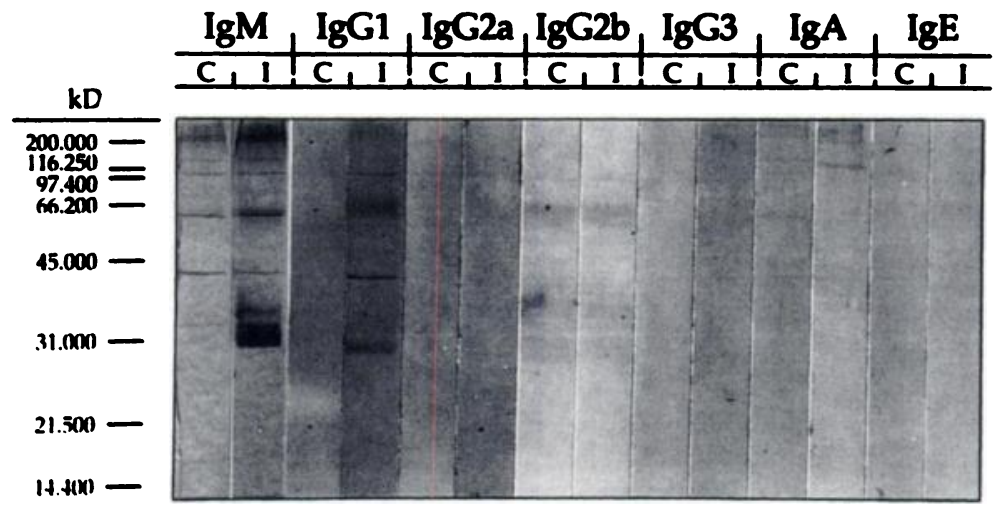

FIGURE 1. Western blot of infective third-stage larvae (L3) proteins using pooled control (C) or immune (I) mouse serum. Isotype-specific L3 antigen recognition was determined using IgM, IgG1, IgG2a, IgG2b, IgG3, IgA, or IgE specific antiserum. 


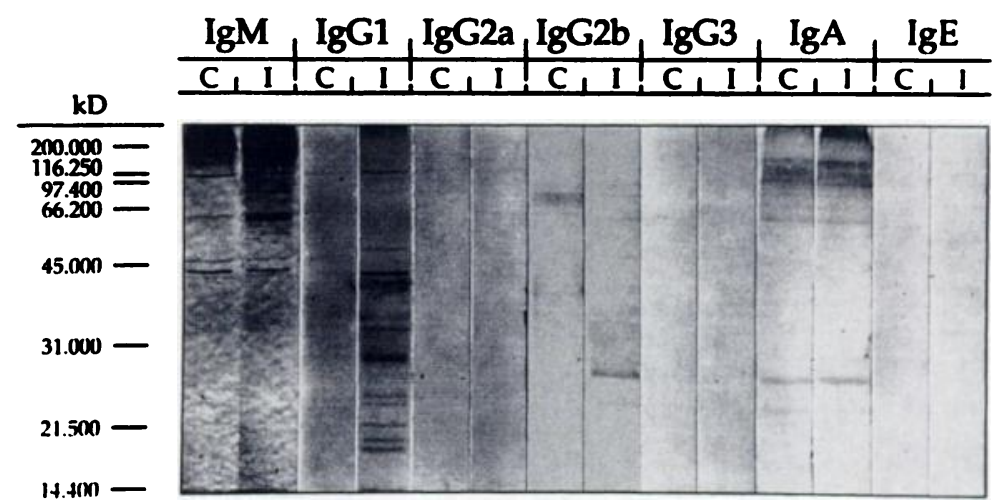

FIGURE 2. Western blot of host-activated third-stage larvae $(\mathrm{L} 3+)$ proteins using pooled control $(\mathrm{C})$ or immune (I) mouse serum. Isotypespecific L3+ antigen recognition was determined using IgM, IgG1, IgG2a, IgG2b, IgG3, IgA, or IgE-specific antiserum.

and L3+ preparations (Figures 1 and 2). Several bands with the same $M_{r}$ were common to both $L 3$ and L3+. However, two bands of 24.4 and $22.2 \mathrm{kD}$ were unique to the $\mathrm{L} 3+$, indicating that IgG1 antibodies may react with $\mathrm{L} 3+$ antigens that are either not found on the original inoculating infective larvae or are post-translationally modified, changing the apparent molecular weight without changing the epitope recognized (Figures 1 and 2, and Table 2). The IgG2a, IgG2b, IgG3, IgA, and IgE from immune serum did not specifically recognize any $\mathrm{L3}$ or $\mathrm{L3}+$ antigen (Figures 1 and 2).

The L3a antigens were also immunoblotted using isotypespecific antisera. Figure 3 shows the results of the Western blots. The IgG1 from serum from immunized mice recognized many bands (Figure 3 and Table 2). Most of the bands recognized by $\mathrm{IgG1}$ had an $\mathrm{M}_{\mathrm{r}}$ that corresponded to bands in L3 and L3+ antigen preparations. However, two bands of

TABLE 2

Recognition of Strongyloides stercoralis infective third stage larvae (L3), host-activated third stage larvae $\left(\mathrm{L}^{+}\right)$, and autoinfective third stage larvae (L3a) proteins by serum from mice protectively immune to L3 challenge using IgGI and IgM antiserum

\begin{tabular}{|c|c|c|c|c|c|}
\hline \multicolumn{3}{|c|}{$\begin{array}{l}\text { Protein molecular weights (kD) } \\
\text { detected by immune IgGI }\end{array}$} & \multicolumn{3}{|c|}{$\begin{array}{l}\text { Protein molecular weights (kD) } \\
\text { detected by immune IgM }\end{array}$} \\
\hline L3 & $\mathrm{L3}^{+}$ & L3a & L3 & $\mathrm{L3}^{+}$ & L3a \\
\hline $\begin{array}{l}69 \\
64 \\
61\end{array}$ & $\begin{array}{l}69 \\
64 \\
61\end{array}$ & 64 & 64 & $\begin{array}{l}76.5 \\
61.5\end{array}$ & \\
\hline & & 55 & 60 & $\begin{array}{l}57.5 \\
55\end{array}$ & \\
\hline 45 & $\begin{array}{l}45 \\
42.5\end{array}$ & $\begin{array}{l}45 \\
42.5\end{array}$ & & 42.5 & \\
\hline $\begin{array}{l}38 \\
36 \\
35.5\end{array}$ & $\begin{array}{l}38 \\
36 \\
35.5\end{array}$ & 35.5 & & & \\
\hline & 34.2 & $\begin{array}{l}34.2 \\
33\end{array}$ & $\begin{array}{l}35 \\
34.2\end{array}$ & & \\
\hline 31.5 & 31.5 & 31.5 & $\begin{array}{l}31.5 \\
31\end{array}$ & & \\
\hline 30 & $\begin{array}{l}30 \\
29.5 \\
25.5 \\
24.4 \\
22.2 \\
20.2 \\
18\end{array}$ & $\begin{array}{l}30 \\
29.5 \\
25.5\end{array}$ & 30 & & \\
\hline
\end{tabular}

55 and $33 \mathrm{kD}$ were unique to the L3a. Several bands recognized by IgGl, having $M_{r}$ values between 18 and 42.5 $\mathrm{kD}$, appeared to be shared by only the host-dwelling stages, the L3+ and L3a. No L3a antigens were specifically detected by immune IgM, IgG2a, IgG2b, IgG3, IgA, or IgE.

\section{DISCUSSION}

The intestinal nematode $S$. stercoralis produces a wide range of clinical illness in humans. Individuals harboring only small numbers of gastrointestinal worms are often asymptomatic. The chronic nature of strongyloidiasis is thought to be due to autoinfection, in which female worms sporadically produce larvae that develop to infectivity during intestinal transit, resulting in periodic autoreinfection of the host. Hyperinfection occurs when host regulation of the development and survival of the $\mathrm{L} 3 \mathrm{a}$ is lost, leading to a dramatic increase in L3a numbers, and potential dissemination of these larvae throughout all of the major organ systems of the host. The L3a stage is only found in S. stercoralis infections, and therefore has only been studied in humans, ${ }^{2}$ monkeys, ${ }^{3}$ dogs, ${ }^{1,4}$ and jirds. ${ }^{5}$ The related species $S$. ratti and S. venezuelensis, which can infect the mouse, do not have an autoinfective stage. ${ }^{26.27}$ Thus, L3a have been difficult to study in an immunologically well-defined system.

In this study, we determined that mice immunized with L3 could not kill L3a implanted in diffusion chambers, although challenge L3 were killed; similar results were obtained in four separate experiments. The difference observed between the L3 and L3a controls are due to the harvest and handling procedures of the L3a prior to implantation. The L3a is a stage solely relegated to an in vivo environment. The several hours of processing outside the host milieu appear to effect the L3a general survival. However, once inside the experimental animal, they survive equally well whether or not the animal was immunized with L3. The L3a also survive significantly better than the L3 in mice immunized with L3. Several components of immunity were analyzed to determine the cause for L3a survival in immunized mice. Previous experiments showed that eosinophils, IgM, and complement were necessary for killing L3 challenge infections. ${ }^{10.11}$ Eosinophils were the only cells that increased in number in diffusion chambers containing L3a (Table 1). Their numbers were equivalent to those recovered from dif- 


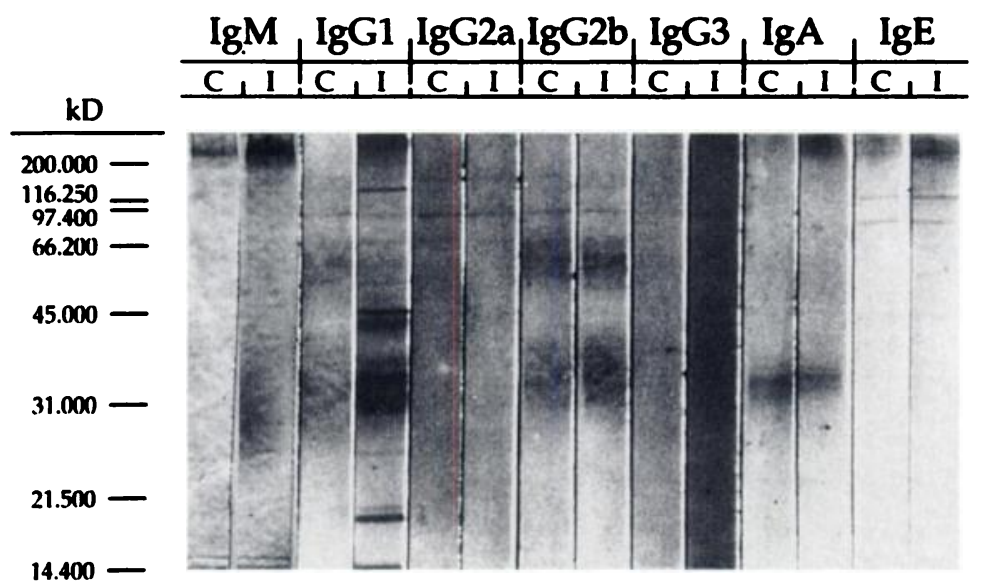

FigURE 3. Western blot of autoinfective third-stage larvae (L3a) proteins using pooled control (C) or immune (I) mouse serum. Isotypespecific L3a antigen recognition was determined using IgM, IgG1, IgG2a, IgG2b, IgG3, IgA, or IgE-specific antiserum.

fusion chambers containing infective L3. Furthermore, immune IgM bound to the surface of $\mathrm{L3a}$ and there were no discernible differences seen between IgM binding to the surfaces of L3 and L3a. One reason for the resistance of L3a to immune-mediated mechanisms that kill L3 might be a lack of complement fixation. It is possible that the surface of L3a does not allow C3 fixation or perhaps it readily sheds attached complement. Other parasites, including Schistosoma mansoni and Trypanosoma cruzi, ${ }^{28-30}$ have immune evasion mechanisms involving interference with the complement pathway.

Another explanation for the lack of L3a killing would be the absence of specific antigen recognition by immune IgM as seen on the Western blots, although immune IgM appears to bind equally to L3 and L3a larval surfaces. Equal surface staining may be due to recognition of common polysaccharides or proteoglycans not seen by Western blotting. Alternatively, a protective surface antigen not shared by L3 and L3a may be present but undetectable by surface staining due to the overwhelming intensity of common polysaccharide or proteoglycan recognition. Finally, a protective somatic antigen might not be shared between the L3 and L3a, and the binding of immune IgM to the larval surface could be irrelevant. This would seem to be the case in this study since IgM from immune serum did not recognize any L3a proteins. In contrast, many antigens were recognized by immune IgM in both L3 and L3+ preparations. It is reasonable to conclude that these differences in antigen recognition between larvae, especially the relative lack of total antigen recognition in L3a preparations, could be responsible for the resistance of $\mathrm{L} 3 \mathrm{a}$ to $\mathrm{L} 3$ killing mechanisms. The IgGl from immune serum recognizes many more protein bands than IgM in Western blots in this study. This is not surprising, since IgGl is elevated in serum from mice immunized with $S$. stercoralis larvae as measured by parasite-specific ELISA. ${ }^{8}$ Although IgG1 antibody levels are elevated, IgG1 is not essential for protective immunity to $S$. stercoralis L3." High levels of $\mathrm{IgG1}$ indicate that T helper cell 2 (Th2)-type responses have been generated in the immunized mice. ${ }^{31}$

The findings that eosinophils increase in number in mice immunized with L3, and that there is an influx of eosinophils in diffusion chambers containing both $\mathrm{L3}$ and L3a, are of great significance. General inflammatory reactions are not responsible for this increase in eosinophils, since mice that were not immunized with L3 did not have a high number of eosinophils present in their implanted diffusion chambers. Elevated levels of eosinophils adds further evidence that a Th2 response has been activated in the immunized mice. ${ }^{32}$ When eosinophil levels are reduced in $S$. stercoralis-immunized mice, immunity to $\mathrm{L} 3$ is also diminished. ${ }^{10}$ The fact that eosinophils are present in the microenvironment of $\mathrm{L3a}$, yet L3a are not killed, is further indication that a missing immune component may be responsible for the lack of L3a killing.

The L3 change antigenically once within the mouse host, and antibodies from immune mouse serum react differently to L3+ antigens than to L3 antigens (Table 2). The difference in antigen recognition may be due to the recognition of previously unexpressed proteins. Alternatively, the difference may be due to glycosylation of existing proteins that changes the relative mobility on the SDS-PAGE while the epitope recognized remains unchanged. Finally, the difference in recognition may also be a combination of these two possibilities. Work in this system with $S$. stercoralis and work in the rat with $S$. venezuelensis indicates that temperature shift may play an important role in signaling development into the L3+ stage. ${ }^{18}$ The antigens found to be L3+ specific in $S$. venezuelensis tend to be of lower molecular weight, which is consistent with what was found in this study. ${ }^{18}$ Whether these bands represent the expression of new antigens that are immunoprotective or just immunodominant remains to be determined. Strongyloides stercoralis L3+ have been shown, however, to be susceptible to killing by eosinophil granule products, while L3 are resistant to these molecules. ${ }^{10}$ This indicates that $\mathrm{L} 3$ must undergo some degree of antigenic change before they can be killed by the host immune system. Since L3a are also host-adapted larvae, it is likely that they are expressing antigens that block a protective immune response that would kill $\mathrm{L3+}$, or they have lost antigens that would cause them to become susceptible to immune-mediated killing.

Chronicity of $S$. stercoralis infection may be due to the production of L3a maintaining the adult worm population over time. The results of this study demonstrate that while 
exposure of the host to infective larvae results in high levels of protective immunity to challenge $\mathrm{L} 3 / \mathrm{L} 3+$, autoinfective larvae are unaffected by this immunity. Dissociation of immunity between stages has been seen with $\mathrm{L} 3$ and adult $S$. ratti infections in the rat and mouse. ${ }^{26.33}$ This would explain why L3a in human hosts are not killed by the immune system, and would enable the infection to exist for decades. Incoming infective larvae would be targeted by the immune response, however, and this protection would thus prevent superinfection with the parasite. By manipulating the host immune system in this way, $S$. stercoralis thus enables itself to survive for the lifetime of its host, while preventing high levels of infection which may be deleterious to the host.

Acknowledgments: We thank Ofra Leon and Wiboonchai Yutanawiboonchai for expert technical assistance.

Financial support: This research was supported in part by grants from the Edna McConnell Clark Foundation and by NIH grant ROIAI-22662. Richard A. Brigandi was supported in part by a Percival E. and Ethel Brown Foerderer Fellowship.

Authors' addresses: Richard A. Brigandi, Harris L. Rotman, and David Abraham, Department of Microbiology and Immunology, Kimmel Cancer Center, Thomas Jefferson University, 233 South 10th Street, Philadelphia, PA 19107. Thomas J. Nolan and Gerhard A. Schad, Department of Pathobiology, University of Pennsylvania, School of Veterinary Medicine, 3800 Spruce Street, Philadelphia, PA 19103.

Reprint requests: David Abraham, Department of Microbiology and Immunology, Kimmel Cancer Center, Thomas Jefferson University, 233 South 10th Street, Philadelphia, PA 19107.

\section{REFERENCES}

1. Schad GA, Smith G, Megyeri Z, Bhopale VM, Niamatali S, Maze R, 1993. Strongyloides stercoralis: an initial autoinfective burst amplifies primary infection. Am J Trop Med Hyg 48: 716-725.

2. Igra-Siegman Y, Kapila R, Sen P, Kaminski C, Louria DB, 1981. Syndrome of hyperinfection with Strongyloides stercoralis. Rev Infect Dis 3: 397-407.

3. Barrett KE, Neva FA, Gam AA, Cicmanec J, London WT, Phillips JM, Metcalfe DD, 1988. The immune response to nematode parasites: modulation of mast cell numbers and function during Strongyloides stercoralis infections in nonhuman primates. Am J Trop Med Hyg 38: 574-581.

4. Grove DI, Northern C, 1982. Infection and immunity in dogs infected with a human strain of Strongyloides stercoralis. Trans $R$ Soc Trop Med Hyg 76: 832-838.

5. Nolan TJ, Megyeri Z, Bhopale VM, Schad GA, 1993. Strongyloides stercoralis: the Mongolian gerbil (Meriones unguiculatus), the first rodent model for uncomplicated and hyperinfective strongyloidiasis. $J$ Infect Dis 168: 1479-1484.

6. Cappello M, Hotez PJ, 1993. Disseminated strongyloidiasis. Semin Neurol 13: 169-174.

7. Dawkins HJS, Grove DI, 1982. Attempts to establish infections with Strongyloides stercoralis in mice and other laboratory animals. J Helminthol 56: 23-26.

8. Abraham D, Rotman HL, Haberstroh HF, Yutanawiboonchai W, Brigandi RA, Leon O, Nolan TJ, Schad GA, 1995. Strongyloides stercoralis: protective immunity to third-stage larvae in BALB/cByJ mice. Exp Parasitol 80: 297-307.

9. Rotman HL, Yutanawiboonchai W, Brigandi RA, Leon O, Nolan TJ, Schad GA, Abraham D, 1995. Strongyloides stercoralis: complete life cycle in SCID mice. Exp Parasitol 81: 136139.

10. Rotman HL, Yutanawiboonchai W, Brigandi RA, Leon $O$, Gleich GJ, Nolan TJ, Schad GA, Abraham D, 1996. Strongyloides stercoralis: eosinophil-dependent immune-mediated killing of third stage larvae in BALB/cByJ mice. Exp Parasitol 82: 267-278.

11. Brigandi RA, Rotman HL, Yutanawiboonchai W, Leon O, Nolan TJ, Schad GA, Abraham D, 1996. Strongyloides stercoralis: role of antibody and complement in immunity to the third stage of larvae in BALB/cByJ mice. Exp Parasitol 82: 279289.

12. Nolan TJ, Rotman HL, Bhopale VM, Schad GA, Abraham D, 1995. Immunity to a challenge infection of Strongyloides stercoralis third-stage larvae in the jird. Parasite Immunol 17: 599-604.

13. Murrell KD, Graham CE, 1983. Shedding of antibody complexes by Strongyloides ratti (Nematoda) larvae. J Parasitol 69: 70-73.

14. Grove DI, Northern C, Warwick A, Lovegrove FT, 1984. Loss of surface coat by Strongyloides ratti infective larvae during skin penetration: evidence using larvae radiolabelled with 67gallium. J Parasitol 70: 689-693.

15. McHugh TD, Jenkins T, McLaren DJ, 1989. Strongyloides ratti: studies of cutaneous reactions elicited in naive and sensitized rats and of changes in surface antigenicity of skin-penetrating larvae. Parasitology 98: 95-103.

16. Tsuji N, Fujisaki K, 1994. Development in vitro of free-living infective larvae to the parasitic stage of Strongyloides venezuelensis by temperature shift. Parasitology 109: 643-648.

17. Grove DI, Northern C, Dawkins HJS, 1985. Interactions of Strongyloides ratti free-living and skin-penetrated infective larvae and parasitic adults with serum and cells in vitro. Aust J Exp Biol Med Sci 63: 521-529.

18. Grove DI, Warton A, Northern C, Papadimitriou JM, 1987. Electron microscopical studies of Strongyloides ratti infective larvae: loss of the surface coat during skin penetration. $J$ Parasitol 73: 1030-1034.

19. Schad GA, 1989. Morphology and life history of Strongyloides stercoralis. Grove DI, ed. Strongyloidiasis: A Major Roundworm Infection of Man. New York: Taylor \& Francis, 85104.

20. Genta RM, Douce RW, Walzer PE, 1986. Diagnostic implications of parasite-specific immune responses in immunocompromised patients with strongyloidiasis. J Clin Microbiol 23: 1099-1103.

21. Hawdon JM, Schad GA, 1991. Long term storage of hookworm infective larvae in buffered saline solution maintains larval responsiveness to host signals. J Helminthol Soc (Wash) 58: 140-142.

22. Laemmli UK, 1970. Cleavage of structural proteins during the assembly of the head of bacteriophage T4. Nature 227: 680-685.

23. Shapiro AL, Vinuela E, Maizel J Jr, 1967. Molecular weight estimation of polypeptide chains by electrophoresis in SDS-polyacrylamide gels. Biochem Biophys Res Comm 28: 815-820.

24. Towbin H, Staehelin T, Gordon J, 1979. Electrophoretic transfer of proteins from polyacrylamide gels to nitrocellulose sheets: procedure and some applications. Proc Nat Acad Sci USA 76: 4350-4354.

25. Awobuluyi M, Maina CV, Carlow CK, 1991. Cross-linking of a monoclonal antibody-antigen complex enables detection of parasite antigen in immunoblots and in an expression library. Mol Biochem Parasitol 44: 149-152.

26. Murrell KD, 1980. Strongyloides ratti: acquired resistance in the rat to the preintestinal migrating larvae. Exp Parasitol 50: 417-425.

27. Sato Y, Toma H, 1990. Strongyloides venezuelensis infections in mice. Int J Parasitol 20: 57-62.

28. Pearce EJ, Basch PF, Sher A, 1986. Evidence that the reduced surface antigenicity of developing Schistosoma mansoni schistosomula is due to antigen shedding rather than host molecule acquisition. Parasite Immunol 8: 79-94.

29. Marikovsky M, Amon R, Fishelson Z, 1988. Proteases secreted by transforming schistosomula of Schistosoma mansoni promote resistance to killing by complement. J Immunol 141 273-278.

30. Sher A, Hieny S, Joiner K, 1986. Evasion of the alternate complement pathway by metacyclic trypomastigotes of Trypanosoma cruzi: dependence of developmentally regulated synthe- 
sis of surface protein and N-linked carbohydrate. J Immunol 147: 2961-2967.

31. Mosmann TR, Cherwinski H, Bond MW, Giedlin MA, Coffman $R L, 1986$. Two types of murine helper $T$ cell clone. I. Definition according to profiles of lymphokine activities and secreted proteins. J Immunol 136: 2348-2357.
32. Coffman RL, Seymour BW, Hudak S, Jackson J, Rennick D, 1989. Antibody to interleukin-5 inhibits helminth-induced eosinophilia in mice. Science 245: 308-310.

33. Grove DI, Northern C, 1989. Dissociation of the protective immune response in the mouse to Strongyloides ratti. $J \mathrm{Hel}$ minthol 63: 307-314. 